\title{
AMPHIBIANS AND REPTILES IN THE CAVES OF THE GREATER CAUCASUS
}

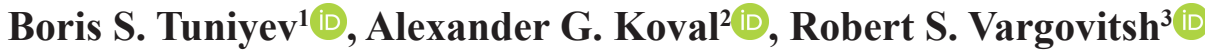 \\ ${ }^{1}$ Sochi National Park, Russia \\ e-mail:btuniyev@mail.ru \\ ${ }^{2}$ All-Russian Institute of Plant Protection, Russia \\ e-mail:agkoval@yandex.ru \\ ${ }^{3}$ I.I. Schmalhausen Institute of Zoology, Ukraine \\ e-mail:arete@izan.kiev.ua
}

Received: 14.10.2020. Revised: 08.12.2020. Accepted: 10.12.2020.

\begin{abstract}
The present study is the first review of the recent herpetofauna of the Greater Caucasian caves. Also, it is worth noting some phossylous material on amphibians and reptiles (mainly Pleistocene remains) from the caves in this area. The goal of the study is to fill knowledge gaps and to present long-term data on the cave herpetofauna of the Greater Caucasus. In 1992-2019, amphibians and reptiles were found in 61 Greater Caucasian caves located in an altitude range from $55 \mathrm{~m}$ a.s.l. to $1300 \mathrm{~m}$ a.s.l. in Russia, Abkhazia, and Georgia. A total of 272 specimens representing ten species have been found. The most frequently observed species were Rana macrocnemis (39.0\% of all recorded specimens), Pelodytes caucasicus (17.3\%), Bufo verrucosissimus $(11.0 \%)$, Darevskia brauneri (8.8\%), Hyla orientalis $(8.1 \%)$. The total proportion of the remaining five species (Ommatotriton ophryticus, Hyla savignyi, Pelophylax ridibundus, Anguis colchica, and Darevskia derjugini) was $15.8 \%$. As a rule, representatives of the herpetofauna in the Greater Caucasian caves are quite rare and only single or few individuals are usually found. Exceptions were Fyodorovskaya Cave (Black Sea Region near the city of Sochi), Akshasha Cave, Abshdza Cave and Marshania Verkhnyaya Cave (last three in Abkhazia) where 141 specimens of amphibians and reptiles were observed, i.e. more than half $(51.8 \%)$ of the totally recorded specimens. They belong to eight species ( $80.0 \%$ of all species found). The caves of the Greater Caucasus foothills, where the vast majority of amphibians and reptiles were observed, are usually characterised by a rich faunal diversity of invertebrate animals - their potential food. Amphibians were recorded from both twilight and deep parts of the caves, whereas lizards were found mainly close to the entrances, where the light penetrates and a relatively high air temperature is observed in the warm period of the year. Probably, some of the Greater Caucasian amphibians and reptiles enter the caves purposefully for wintering, and/or for feeding. The other animals occur accidentally in the caves (especially on the bottom of vertical pits), becoming «prisoners of circumstances». Judging by the length of time spent in the caves and, as a consequence, the change in body pigmentation (lighting of the main colouration tone) and good external condition of many individuals, these amphibians can be considered subtroglophiles. Rana macrocnemis, capable of laying eggs in caves, shows a tendency for eutroglophily.
\end{abstract}

Key words: Abkhazia, eutroglophile, Georgia, herpetofauna, Russia, Sochi National Park, subtroglophile, underground cavity

\section{Introduction}

The present study is the first review of the herpetofauna of the Greater Caucasian caves. As far as the adjacent territories are concerned, a detailed survey of the cave herpetofauna has been published only for the Crimea, where four species of amphibians and eight species of reptiles were recorded (Turbanov et al., 2015, 2019; Kukushkin et al., 2017). In Western Ukraine (Carpathians and Podolia), five species of amphibians are shown to be common in caves (Krochko, 1973; Zagorodniuk \& Petrushenko, 2003; Vargovitsh \& Monich, 2004; Zagorodniuk \& Vargovitsh, 2004).
To date, several scattered records of amphibians and reptiles from the caves of the Greater Caucasus have been noted. Particularly, the records from Sochi National Park are: Anguis fragilis Linnaeus, 1758 (=A. colchica (Nordmann, 1840)) in Chyortova Nora Cave (Agura Gorge) (Koval, 2004a), Ommatotriton ophryticus (Berthold, 1846) in Pechalnaya Cave on the Dzykhra Ridge (previously incorrectly listed as the Akhtsu Ridge) and in Nazarovskaya Cave on the Alek Ridge, at a depth of 400 m (Tuniyev et al., 1987; Tuniyev \& Tuniyev, 2006a,b), Bufo verrucosissimus in Vorontsovskaya Cave, on the bottom of the pit, $\sim 200 \mathrm{~m}$ from entrance (Tuniyev \& Tuniyev, 2007b). 
In the Republic of Karachay-Cherkessia (hereafter - Karachay-Cherkessia), two specimens of Ommatotriton ophryticus were found in Malaya Grina Cave in the basin of the River Bolshoy Zelenchuk and one specimen in a cave on the Gromatukha Plateau on the left bank of the River Urup. The Zoological Museum of Moscow University holds a specimen of $O$. ophryticus (№1230) from a nameless karsthole on the Bzyb Mountain Range in Abkhazia (Tuniyev et al., 1987; Tuniyev \& Tuniyev, 2006b). The find of Rana macrocnemis Boulenger, 1885 was mentioned from Novoafonskaya Cave (Kapralov, 2017). The find of Hyla savignyi Audouin, 1827 was noted from Samshitovaya Cave in Abkhazia (Tuniyev, 2017).

This study is aimed to fill knowledge gaps in this area and to present long-term data on the cave herpetofauna of the Greater Caucasus.

\section{Material and Methods}

In 1992-2019, studies were carried out in 61 caves of the Greater Caucasus in Russia, Abkha- zia, and Georgia (Fig. 1). The primary research was done in the West Caucasus: in 24 caves of Abkhazia and 36 caves of Russia, including 31 in the city of Sochi vicinities (Sochi National Park) and two caves in Karachay-Cherkessia. Material from the Apsheron district of the Krasnodarsky Krai (= Krasnodar Territory) was also studied. Additionally, three caves in the Central Caucasus, Russia (Republic of KabardinoBalkaria (hereafter - Kabardino-Balkaria), Republic of North Ossetia-Alania (hereafter North Ossetia-Alania)) and Georgia (Terzhola district) were investigated. Amphibians and reptiles were found in caves located in an altitude range from $55 \mathrm{~m}$ a.s.1. to $1300 \mathrm{~m}$ a.s.1.

For each record, the horizontal distance and the vertical depth from the entrance of the cave are given. The condition of the animals and the peculiarities of their coloring were assessed. Animals were photographed. Some specimens were fixed in $96 \%$ ethanol and stored in Sochi National Park (SNP) collection.

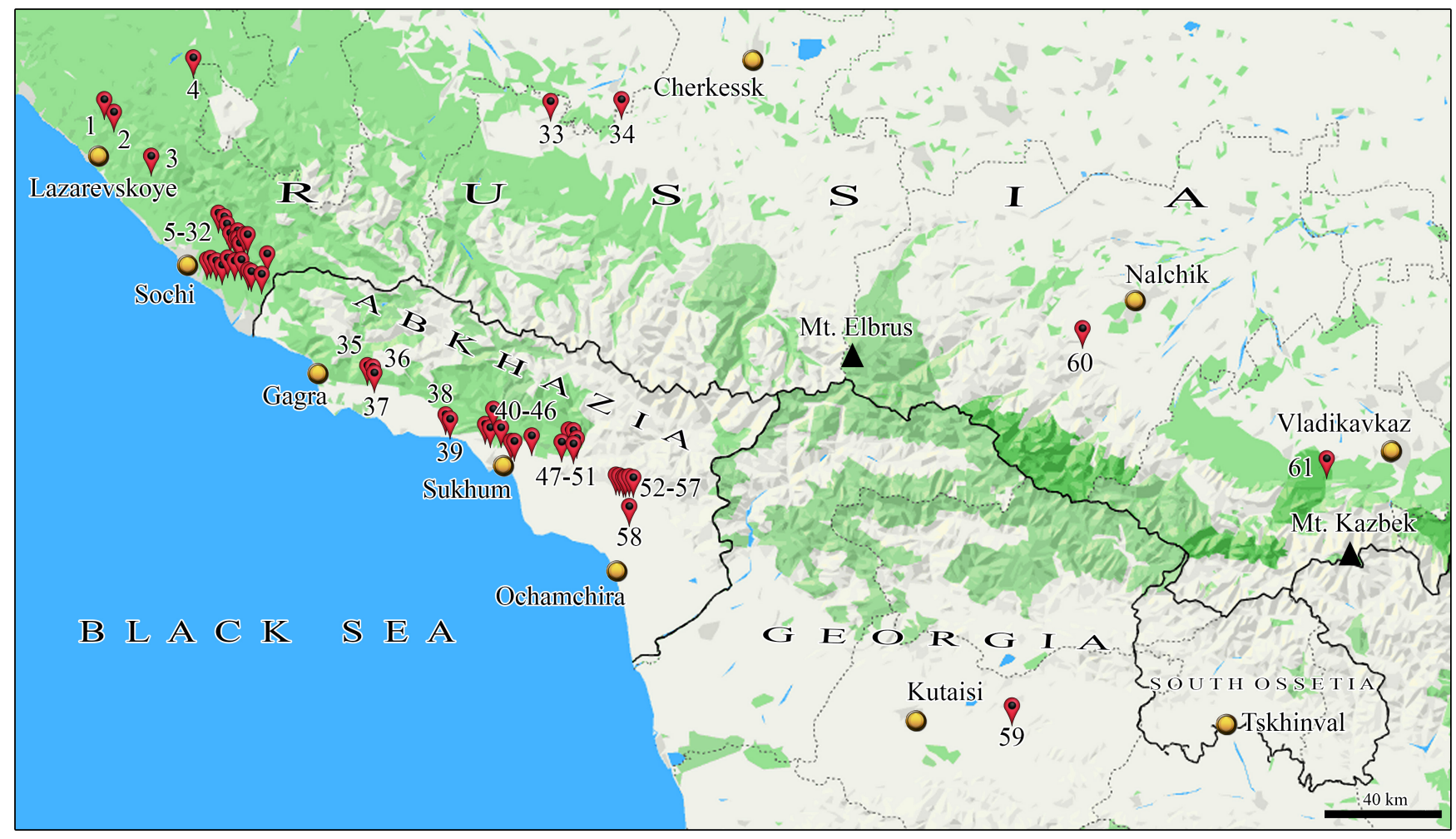

Fig. 1. The map of the study area with marked caves. Designations of the caves: 1 - Krasnoaleksandrovskaya, 2 Kirovskaya, 3 - Lyagushachya, 4 - Kanyon, 5 - Atsinskaya, 6 - Gigantov, 7 - Osennyaya, 8 - Nazarovskaya, 9 Partizanskaya, 10 - Pauchka, 11 - Ametist, 12 - Eksperimentalnaya, 13 - Fyodorovskaya, 14 - Yurskaya, 15 - K-16, 16 Vorontsovskaya, 17 - Labirintovaya, 18 - Kabanya, 19 - Dolgaya, 20 - Chyortova Nora, 21 - Akhunskaya, 22 - AKHN-6, 23 - Beloskalskaya, 24 - Bochka, 25 - Oblomnaya, 26 - Shirokopokosskaya, 27 - Kolokolnaya, 28 - Kievlyanka, 29 Malaya Kazachebrodskaya, 30 - Bolshaya Kazachebrodskaya, 31 - Berezhnogo, 32 - Pechalnaya, 33 - nameless cave, 34 - Malaya Grina, 35 - Akshasha, 36 - Abshdza, 37 - Otkharskaya, 38 - Maanikvarskaya, 39 - Abkhazskikh Speleologov, 40 - Verkhneesherskaya, 41 - Adzaba, 42 - Andreevskaya, 43 - Mikhaylovskaya, 44 - Besletskaya I, 45 - Besletskaya II, 46 - Kelasurskaya, 47 - Tsebeldinskaya, 48 - Verkhnyaya Shakuranskaya, 49 - Vodopadnaya, 50 - Kholodnaya, 51 Dzhampalskaya I, 52 - Kotsha, 53 - Dzykhayskaya, 54 - Golova Otapa, 55 - Nad Golovoy Otapa, 56 - Samshitovaya, 57 - Marshania Verkhnyaya, 58 - Dzhalskaya I, 59 - Samchikiya, 60 - Omega-15 (= NSS-53), 61 - Nyvdzhin Lagat. 
We used the classification of Racovitza (1907) modified by Sket (2008) for animal groups found in caves as follows: a) trogloxenes are species occurring only sporadically in hypogean habitats and unable to establish subterranean populations; b) subtroglophiles are species inclined to perpetually or temporarily inhabit subterranean habitats but are intimately associated with epigean habitats for some biological functions (daily, seasonally or during the life cycle); c) eutroglophiles are essentially epigean species capable of maintaining permanent subterranean populations; d) troglobionts are species strictly associated with hypogean habitats and not occurring on the surface.

\section{Results}

In the caves of the Greater Caucasus, 272 specimens of amphibians and reptiles belonging to ten species (seven species of amphibians and three species of reptiles) were found. Below is an annotated list of these species.

Amphibia Gray, 1825

Order Caudata Fischer von Waldheim, 1813

Family Salamandridae Goldfuss, 1820

1. Ommatotriton ophryticus (Berthold, 1846). In total, 17 specimens were recorded. Locations: 1) Russia, Krasnodarsky Krai, Sochi National Park, Alek Ridge, Gigantov Cave, at a depth of 50 m (hereafter in annotated list is indicated as «-50 m»), 03.09.2012, 1 specimen, coll. O.A. Petrov (SNP, №870); 2) Alek Ridge, Osennyaya Cave, near bottom of entrance pit, $\sim-50 \mathrm{~m}$, among rotten logs and other organics, 03.08.2016, 1 specimen, coll. E.F. Doni (SNP, №889); 3) Alek Ridge, Nazarovskaya Cave, -400 m, 1 specimen (Tuniyev et al., 1987; Tuniyev \& Tuniyev, 2006b); 4) West Akhtsu Ridge, Eksperimentalnaya Cave, -32 m, 14.08.2012, 1 specimen, V.A. Gulymanova; 5) West Akhtsu Ridge, Fyodorovskaya Cave, -94 m, on stone ledge $3 \times 2 \mathrm{~m}, 21.08 .2011,1$ specimen, coll. A.M. Karpova, K.B. Sedov (SNP, №882); 6) West Akhtsu Ridge, K-16 Cave, -14 m, 20.07.2018, 1 specimen, D.S. Vakhromov; 7) Dzykhra Ridge, Pechalnaya Cave (= K-3, Katron), 1 specimen (Tuniyev et al., 1987; Tuniyev \& Tuniyev, 2006b); 8) West Akhtsu Ridge, Yurskaya Cave, -20 m, 27.07.2018, 1 specimen, O.A. Inozemtseva; 9) Krasnodarsky Krai, Apsheronsk district: Chernogor Plateau, Kanyon Cave, 01.11.2004, 1 specimen, coll. S.V. Gazaryan (SNP, №847); 10) Russia, Karachay-Cherkessia: basin of River Bolshoy Zelenchuk, Malaya Grina Cave, 2 specimens, V.A. Makukhin (Tuniyev et al., 1987; Tuniyev \& Tuniyev, 2006b); 11) leftbank of RiverUrup, Gromatukha Plateau, nameless cave, 1 specimen, V.A.
Makukhin (Tuniyev et al., 1987; Tuniyev \& Tuniyev, 2006b); 12) Abkhazia, Gulripsh district: left side of gorge of River Kelasur, near the village of Verkhniy Kelasur, Kelasurskaya (= Aleksandrovskaya) Cave, $200 \mathrm{~m}$ from entrance, $\sim-60 \mathrm{~m}, 04.09 .2014,1$ specimen, coll. I.S. Turbanov (SNP, №872) (Fig. 2A); 13) Abkhazia, Ochamchira district: vicinity of the village of Otap (Uatap), Marshania Verkhnyaya (= Marshania II) Cave, on bottom of pit $(-30 \mathrm{~m}), 23.08 .2015,1$ specimen, coll. R.S. Vargovitsh (SNP, №881) (Fig. 2B); 14) Ochamchira district: vicinity of the village of Otap, Marshania Verkhnyaya Cave, on bottom of pit (-30 m), 21.09.2017, 2 specimens, R.S. Vargovitsh; 15) Ochamchira district: vicinity of the village of Otap, Marshania Verkhnyaya Cave, on bottom of pit (-30 m), 19.09.2018, 1 specimen, R.S. Vargovitsh.

Order Anura Fischer von Waldheim, 1813 Family Bufonidae Gray, 1825

2. Bufo verrucosissimus (Pallas, 1814). In total, 30 specimens were recorded. Locations: 1) Russia, Krasnodarsky Krai, Sochi National Park: vicinity of the village of Vorontsovka, upper part of canyon of River Vostochnaya Khosta, Partizanskaya Cave, $40 \mathrm{~m}$ from entrance, 29.08.1992, 1 specimen, A.G. Koval; 2) vicinity of the village of Vorontsovka, Vorontsovskiy Ridge, Dolgaya Cave, $\sim 300 \mathrm{~m}$ from entrance, Glavnaya Gallery, 09.08.2015, 1 specimen, O.A. Petrov; 3) vicinity of the village of Vorontsovka, upper part of River Kudepsta, Vorontsovskaya Cave, on bottom of pit, $\sim 200 \mathrm{~m}$ from entrance, 1 specimen (Tuniyev \& Tuniyev, 2007b); 4) 4 km north-west from the village of Tkhagapsh (= Kirov), valley of River Khekuey (right tributary of River Psezuapse), Kirovskaya (= Tigrovaya, Tkhagapsh) Cave, $30 \mathrm{~m}$ from entrance, 25.05.1995, 1 specimen, A.G. Koval; 5) vicinity of the village of Vorontsovka, West Akhtsu Ridge, Ametist Cave, -20 m, 22.09.2014, 1 specimen, I.S. Turbanov, A.G. Koval; 6) West Akhtsu Ridge, Fyodorovskaya Cave, $-94 \mathrm{~m}$, on stone ledge $3 \times 2 \mathrm{~m}$, 21.08.2011, 1 specimen, A.M. Karpova, K.B. Sedov; 7) West Akhtsu Ridge, Pauchka Cave, at bottom (-60 m), 19.09.2019, 2 specimens, O.V. Merkuriev, A.A. Chumachkov, S.V. Yashin; 8) Alek Ridge, Osennyaya Cave, near bottom of entrance pit, $\sim-50 \mathrm{~m}$, among rotten logs and other organics, 03.08.2016, 1 specimen, E.V. Doni; 9) Alek Ridge, Gigantov Cave, -100 m, 01.08.2017, 1 specimen, D.S. Vakhromov; 10) vicinity of the village of Ermolovka, Akhshtyr karst massif, Berezhnogo Cave, -25 m, 23.09.2018, 1 specimen, N.V. Muzalevskaya; 11) vicinity of the village of Ermolovka, Akhshtyr karst massif, Berezhnogo Cave, $\sim-20 \mathrm{~m}, 18.09 .2019,7$ specimens (including 4 
juvenile specimens), R.S. Vargovitsh; 12) vicinity of the village of Krasnaya Volya, Bochka Cave, $-5 \mathrm{~m}$ to -10 m, 01.10.2018, 1 specimen, R.S. Vargovitsh; 13) Dzykhra Ridge, Pechalnaya Cave, $\sim 600 \mathrm{~m}$ from entrance, -130 m, 14.09.2019, 1 specimen, R.S. Vargovitsh (Fig. 2C); 14) Abkhazia, Gulripsh district: vicinity of the village of Amtkel, Verkhnyaya Shakuranskaya Cave, 05.06.2006, $500 \mathrm{~m}$ from entrance, near water, 1 juvenilespecimen( $\sim 2-3 \mathrm{cmlength})$, R.S. Vargovitsh; 15) Gulripsh district, River Dzhampal, left side of gorge, Dzhampalskaya I Cave, at entrance, 1 specimen, R.S. Vargovitsh, A.G. Koval; 16) vicinity of Sukhum City: valley of River Besletka, near Venetsianskiy (= Besletskiy) Bridge, Besletskaya I Cave, 05.08.2010, 1 specimen, R.S. Vargovitsh, A.G. Koval; 17) Sukhum district: vicinity of the village of Verkhnyaya Eshera, Verkhneesherskaya Cave, $\sim-50$ m, 17.09.2017, 1 spe-

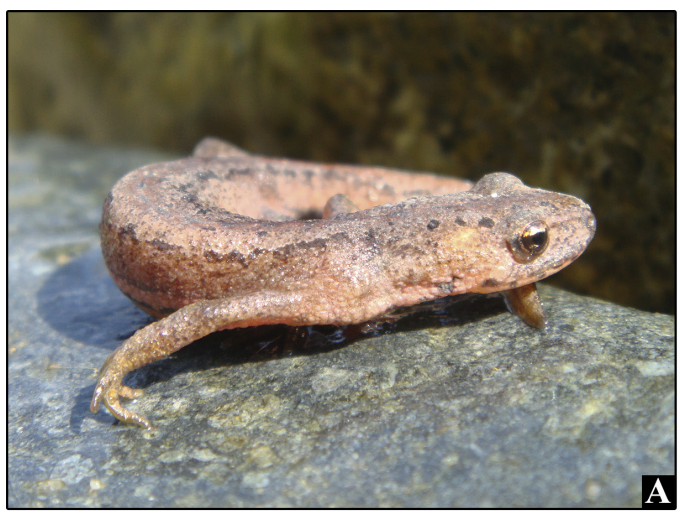

cimen, R.S. Vargovitsh; 18) Ochamchira district: near the village of Dzhal, Dzhalskaya I Cave, near bottom of entrance pit, -6 m, 11.08.2010, 1 specimen, A.G. Koval; 19) vicinity of the village of Otap, Samshitovaya Cave, on bottom of entrance pit, $-20 \mathrm{~m}, 21.08 .2015,1$ specimen, R.S. Vargovitsh, I.S. Turbanov; 20) vicinity of the village of Otap, Marshania Verkhnyaya (= Marshania II) Cave, on bottom of pit (-30 m), 23.08.2015, 1 specimen, R.S. Vargovitsh, I.S. Turbanov; 21) vicinity of the village of Otap, Marshania Verkhnyaya Cave, on bottom of pit (-30 m), 30.06.2016, 1 specimen, R.S. Vargovitsh; 22) vicinity of the village of Otap, Marshania Verkhnyaya Cave, on bottom of pit (-30 m), 21.09.2017, 1 specimen, R.S. Vargovitsh; 23) vicinity of the village of Otap, Marshania Verkhnyaya Cave, on bottom of pit (-30 m), 19.09.2018, 1 specimen, R.S. Vargovitsh.
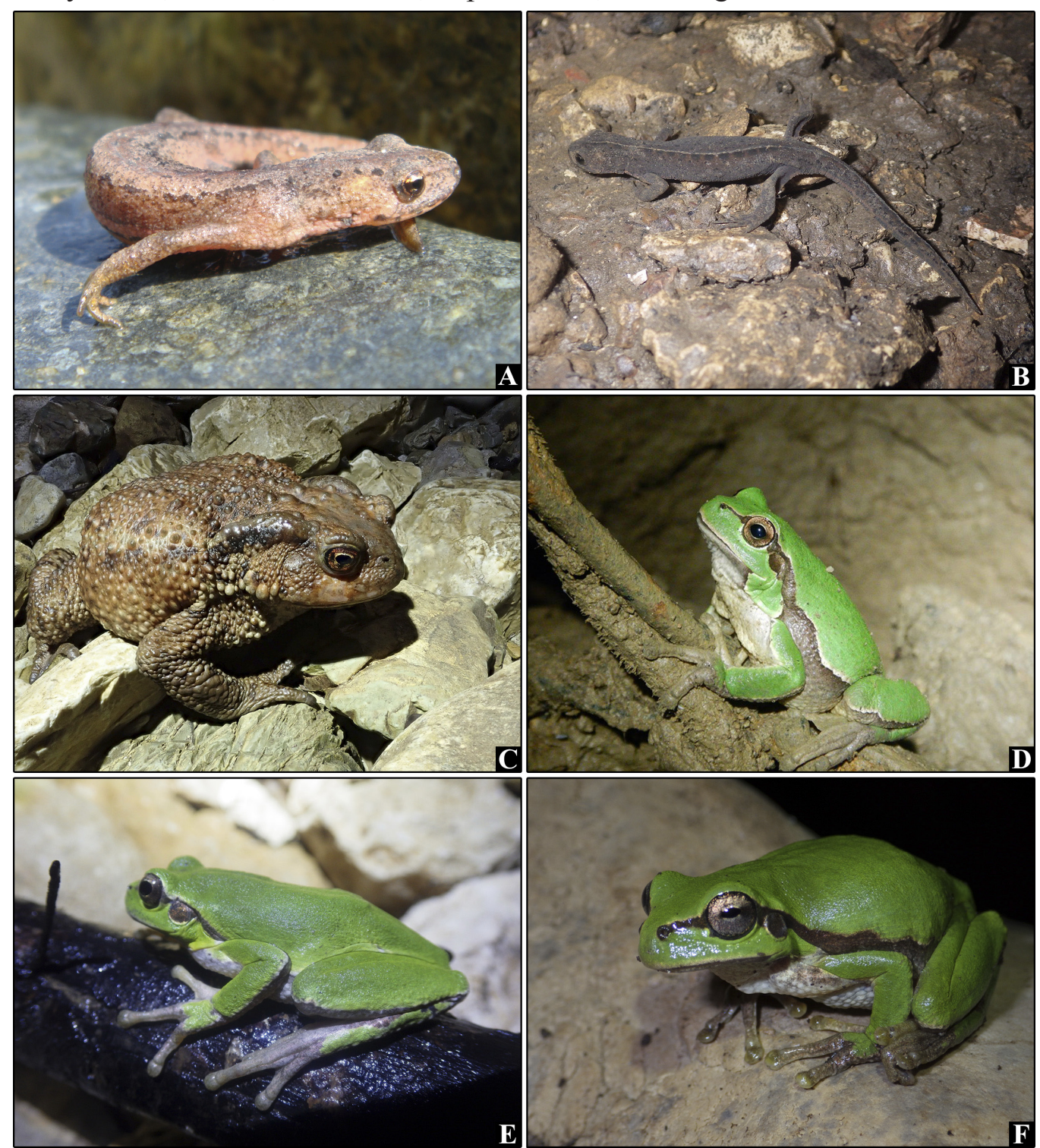

Fig. 2. Amphibians in caves of the West Caucasus. Designations: A - Ommatotriton ophryticus (Abkhazia, Kelasurskaya Cave) (Photo: I.S. Turbanov); B - O. ophryticus (Abkhazia, Marshania Verkhnyaya Cave) (Photo: R.S. Vargovitsh); C Bufo verrucosossimus (Sochi National Park, Pechalnaya Cave) (Photo: R.S. Vargovitsh); D - Hyla orientalis (Abkhazia, Abshdza Cave) (Photo: N.L. Ivanov); E - H. orientalis (Abkhazia, Verkhneesherskaya Cave) (Photo: R.S. Vargovitsh); F - H. savignyi (Abkhazia, Samshitovaya Cave) (Photo: I.S. Turbanov). 
Family Hylidae Rafinesque, 1815

3. Hyla orientalis Bedriaga, 1890. In total, 22 specimens were recorded. Locations: 1) Russia, Krasnodarsky Krai, Sochi National Park: vicinity of the village of Ermolovka, Akhshtyr karst massif, Berezhnogo Cave, $\sim-20 \mathrm{~m}, 18.09 .2019$, 1 specimen, R.S. Vargovitsh; 2) Abkhazia, Gudauta district: vicinity of the village of Blaburkhva, Akshasha (= Tsivi, Kholodnaya) Cave, a part of Mchishta-Akshasha Cave System, -25 m, Kvaksha Hall, 02.05.2015, 2 specimens, N.L. Ivanov, E.Yu. Snetkov; 3) vicinity of the village of Otkhara, Abshdza (= P-1, Krasavitsa) Cave, -22 m, 06.11.2017, 1 specimen, N.L. Ivanov (Fig. 2D); 4) vicinity of the village of Otkhara, Abshdza Cave, $-15 \mathrm{~m}$ to $-255 \mathrm{~m}, 07-10.11 .2018,6$ specimens, E.Yu. Snetkov, I.A. Drachkova; 5) vicinity of the village of Otkhara, Abshdza Cave, -310 m, Yuzhny Siphon, 04.01.2019, 1 specimen, coll. O.A. Kholodnyak (SNP, №1228); 6) vicinity of the village of Otkhara, Abshdza Cave, -10 $\mathrm{m}$ to $-250 \mathrm{~m}, 02.05 .2019,3$ specimens, N.L. Ivanov; 7) vicinity of the village of Otkhara, Abshdza Cave (-10 m to $-250 \mathrm{~m}), 07.11 .2019,6$ specimens, N.L. Ivanov; 8) Sukhum district: vicinity of the village of Verkhnyaya Eshera, Verkhneesherskaya Cave, -50 m, 17.09.2017, 1 specimen, R.S. Vargovitsh (Fig. 2E); 9) Georgia, Terzhola district: spurs of Racha Mountain Range, vicinity of the village of Tuzi, Samchikiya Cave, bottom of pit, $\sim-50 \mathrm{~m}$, and on $\sim 100 \mathrm{~m}$ from entrance, 05.05.2016, 1 specimen, K.V. Bagriy.

4. Hyla savignyi Audouin, 1827. Only one specimen was recorded. Location: 1) Abkhazia, Ochamchira district, vicinity of the village of Otap, Samshitovaya Cave, on bottom of entrance pit, $-20 \mathrm{~m}, 21.08 .2015,1$ specimen, coll. I.S. Turbanov (SNP, №1185) (Fig. 2F).

Family Pelodytidae Bonaparte, 1850

5. Pelodytes caucasicus Boulenger, 1896. In total, 47 specimens were recorded. Locations: 1) Russia, Krasnodarsky Krai, Sochi National Park: vicinity of the village of Vorontsovka, West Akhtsu Ridge, Ametist Cave, -20 m, 22.09.2014, 1 specimen, coll. I.S. Turbanov, A.G. Koval (SNP, №1178); 2) vicinity of the village of Vorontsovka, West Akhtsu Ridge, Fyodorovskaya Cave, $-94 \mathrm{~m}$, on stone ledge $3 \times 2 \mathrm{~m}, 17.08 .2010$, 2 specimens, coll. D.S. Vakhromov (SNP, №1153); 3) vicinity of the village of Vorontsovka, West Akhtsu Ridge, Fyodorovskaya Cave, -94 m, 21.08.2011, 10 specimens, coll. A.M. Karpova, K.B. Sedov (SNP, №1186, 1 specimen); 4) Mt. Akhun (Bolshoy Akhun), downstairs from late restaurant, $\mathrm{H}=585 \mathrm{~m}$ a.s.l., on bottom of AKHN-6 Cave (-7 m), 26.09.2014, 1 specimen, I.S. Turbanov; 5) Alek Ridge, Gigantov Cave,
$-70 \mathrm{~m}$, on stone in brook, 04.05.2015, 1 specimen, V.V. Rystsov; 6) vicinity of the village of Bolshoy Kichmay, Tyupyuchkh Ridge, E of Mt. Kolokolnya, $\mathrm{H}=750 \mathrm{~m}$ a.s.l., Lyagushachya Cave, at bottom of pit $\sim-12 \mathrm{~m}$, 16.07.2015, 3 specimens, coll. I.S. Turbanov (SNP, №1176, 1 specimen); 7) vicinity of the village of Vorontsovka, Vorontsovskaya Cave System, Kabanya (= Kabaniy Proval) Cave, on bottom of entrance pit, -42 m, 10.08.2015, 1 specimen, O.A. Petrov; 8) Mt. Akhun, Akhunskaya Cave, $\sim 20 \mathrm{~m}$ from entrance, 27.07.2016, 1 specimen, R.S. Vargovitsh; 9) vicinity of the village of Krasnaya Volya, Bochka Cave, -10 m, 02.10.2017, 3 specimens, R.S. Vargovitsh; 10) vicinity of the village of Krasnaya Volya, Bochka Cave, $-5 \mathrm{~m}$ to $-10 \mathrm{~m}$, 01.10.2018, 2 specimens, R.S. Vargovitsh; 11) Dzykhra Ridge, Pechalnaya Cave, $\sim 600 \mathrm{~m}$ from entrance, -130 m, 14.09.2019, 3 specimens, R.S. Vargovitsh; 12) Abkhazia, Ochamchira district: vicinity of the village of Otap, Marshania Verkhnyaya (= Marshania II) Cave, on bottom of pit, $-30 \mathrm{~m}, 23.08 .2015,3$ specimens, I.S. Turbanov, R.S. Vargovitsh (Fig. 3A); 13) Ochamchira district: vicinity of the village of Otap, Marshania Verkhnyaya Cave, on bottom of pit, -30 m, 30.06.2016, 2 specimens, R.S. Vargovitsh; 14) Ochamchira district: vicinity of the village of Otap, Marshania Verkhnyaya Cave, on bottom of pit, -30 m, 21.09.2017, 5 specimens, R.S. Vargovitsh; 15) Ochamchira district: vicinity of the village of Otap, Marshania Verkhnyaya Cave, on bottom of pit, -30 m, 19.09.2018, 8 specimens, R.S. Vargovitsh; 16) Ochamchira district: vicinity of the village of Aymara, Kotsha Cave, $-25 \mathrm{~m}$, 20.09.2018, 1 specimen, R.S. Vargovitsh.

Family Ranidae Rafinesque, 1814

6. Rana macrocnemis Boulenger, 1885. In total, 106 specimens were recorded. Locations: 1) Russia, Krasnodarsky Krai, Sochi National Park: vicinity of Khosta Settlement, above of left side of River Khosta gorge, Beloskalskaya Cave, $10 \mathrm{~m}$ from entrance, 01.09.2010, 1 specimen, A.G. Koval; 2) area between the village of Krasnaya Volya and the village of Kazachiy Brod, Akhshtyr karst massif, Kievlyanka Cave, on bottom of entrance pit, -10 m, 26.09.2014, 1 specimen, I.S. Turbanov; 3) Alek Ridge, Osennyaya Cave, near bottom of entrance pit, $\sim-50 \mathrm{~m}$, in water stream, 03.08.2016, 3 specimens, coll. E.F. Doni (SNP, №1189); 4) vicinity of the village of Krasnaya Volya, Bochka Cave, -10 m, 02.10.2017, 1 specimen, R.S. Vargovitsh; 5) vicinity of the village of Krasnaya Volya, Bochka Cave, $-5 \mathrm{~m}$ to $-10 \mathrm{~m}, 01.10 .2018,1$ specimen, R.S. Vargovitsh; 6) vicinity of the village of Krasnaya Volya, Oblomnaya Cave, -15 m, 02.10.2017, 2 specimens, R.S. Vargovitsh; 7) vicinity of the vil- 
lage of Vorontsovka, Vorontsovskaya Cave System, Labirintovaya Cave, $700 \mathrm{~m}$ from entrance, Glavnaya Gallery, near siphon, 18.07.2018, 1 specimen, D.S. Vakhromov; 8) vicinity of the village of Bolshoy Kichmay, Tyupyuchkh Ridge, east of Mt. Kolokolnya, $\mathrm{H}$ $=750 \mathrm{~m}$ a.s.l., Lyagushachya Cave, at bottom of pit, $\sim-12 \mathrm{~m}, 16.07 .2015,2$ specimens, coll. I.S. Turbanov (SNP, №1177); 9) Russia, Kabardino-Balkaria: upper reaches of River Nalchik, Omega-15 (= NSS-53) Cave, $\sim 400 \mathrm{~m}$ from entrance, 23.05.1998, 1 specimen, A.G. Koval; 10) upper reaches of River Nalchik, Omega-15 Cave, $\sim 500 \mathrm{~m}$ from entrance, 02.08.2000, 2 specimens, A.G. Koval; 11) Russia, North Ossetia-Alania, Prigorodny district: Nyvdzhin Lagat Cave $(\mathrm{H}=1095$ $\mathrm{m}$ a.s.1.), $40 \mathrm{~m}$ from entrance, 04.06.2006, 1 specimen, R.A. Tavasiev; 12) Abkhazia, Gulripsh district: village of Tsebelda, Tsebeldinskaya Cave, $\sim 20 \mathrm{~m}$ from entrance, 19.08.2009, 1 specimen, R.S. Vargovitsh; 13) vicinity of the village of Amtkel, base of right side of River Kholodnaya gorge, Vodopadnaya (= Bolshaya Medveditsa) Cave, $\sim 50 \mathrm{~m}$ from entrance, $\sim-20 \mathrm{~m}$, 17.09.2014, 1 specimen, coll. S.A. Bogdanenko (SNP, №1172); 14) vicinity of the village of Amtkel, base of left side of River Kholodnaya gorge, Kholodnaya (= Kharkovskaya, Skhcha) Cave, $\sim 25 \mathrm{~m}$ from entrance, 18.09.2014, 1 specimen, A.G. Koval; 15) Abkhazia, vicinity of Sukhum City: valley of River Besletka, near of Venetsianskiy (= Besletskiy) Bridge, Besletskaya II Cave, 05.08.2010, 1 specimen, R.S. Vargovitsh, A.G. Koval; 16) Abkhazia, Sukhum district: vicinity of the village of Guma (= Mikhaylovskoe, Shroma), Mikhaylovskaya (= Sukhumskaya, Shroma) Cave, $10 \mathrm{~m}$ from entrance, 04.07.2016, 1 specimen, A.G. Koval; 17) vicinity of the village of Verkhnyaya Eshera, Adzaba Cave, $\sim 150 \mathrm{~m}$ from entrance, near siphon, 25.09.2012, 1 specimen, coll. R.S. Vargovitsh (SNP, №1170); 18) near the village of Akhalsheni (= Andreevskoe), Andreevskaya (=Akhalsheni) Cave, $30 \mathrm{~m}$ from entrance, 29.08.2011, 1 specimen, R.S. Vargovitsh; 19) Abkhazia, Ochamchira district: village of Otap, Golova Otapa Cave, $\sim 50 \mathrm{~m}$ from lower entrance, 07.08.2010, 1 specimen, A.G. Koval; 20) Ochamchira district: village of Otap, Golova Otapa Cave, $30 \mathrm{~m}$ from lower entrance, 11.08.2011, 1 specimen, R.S. Vargovitsh, A.G. Koval; 21) Ochamchira district: village of Otap, Golova Otapa Cave, 30-50 m from lower entrance, 23.09.2017, 2 specimens, A.G. Koval; 22) vicinity of the village of Otap, gorge of River Dzykhay, Dzykhayskaya Cave, $\sim 20 \mathrm{~m}$ from entrance, 07.09.2012, 1 specimen, A.G. Koval; 23) vicinity of the village of Otap, Marshania Verkhnyaya (= Marshania II) Cave, on bottom of entrance pit, $-30 \mathrm{~m}, 23.08 .2015,6$ specimens, R.S. Vargovitsh, I.S. Turbanov; 24) vicinity of the village of
Otap, Marshania Verkhnyaya Cave, on bottom of entrance pit, -30 m, 30.06.2016, 1 specimen, R.S. Vargovitsh; 25) vicinity of the village of Otap, Marshania Verkhnyaya Cave, on bottom of entrance pit, $-30 \mathrm{~m}$, 21.09.2017, 4 specimens, R.S. Vargovitsh; 26) vicinity of the village of Otap, Marshania Verkhnyaya Cave, on bottom of entrance pit, $-30 \mathrm{~m}, 19.09 .2018$, 1 specimen, R.S. Vargovitsh (Fig. 3B); 27) vicinity of the village of Aymara, Kotsha Cave, -25 m, 22.09.2017, 1 specimen, R.S. Vargovitsh; 28) Gudauta district: vicinity of the village of Blaburkhva, Akshasha (= Tsivi, Kholodnaya) Cave, a part of Mchishta-Akshasha Cave System, -25 m, Kvaksha Hall, 02.05.2015, 30 specimens, N.L. Ivanov, E.Yu. Snetkov (Fig. 4A); 29) Gudauta district: vicinity of the village of Blaburkhva, Akshasha Cave, -25 m, Kvaksha Hall, 07.11.2015, 16 specimens, N.L. Ivanov; 30) Gudauta district: vicinity of the village of Blaburkhva, Akshasha Cave, -25 m, Kvaksha Hall, 06.01.2016, 12 specimens, N.L. Ivanov; 31) Gudauta district: vicinity of the village of Blaburkhva, Akshasha Cave, -25 m, Kvaksha Hall, 05.05.2016, 1 juvenile specimen, coll. A.S. Bobunova (SNP, №1191); 32) vicinity of Novy Afon town, right side of River Psyrtskha gorge, Maanikvarskaya (= Maly Proval) Cave, at bottom $(-70 \mathrm{~m})$ of entrance pit, 18.07.2016, 1 specimen, R.S. Vargovitsh; 33) vicinity of Novy Afon town, right side of River Psyrtskha gorge, Maanikvarskaya (= Maly Proval) Cave, at bottom $(-70 \mathrm{~m})$ of entrance pit, 18.09.2017, 5 specimens, R.S. Vargovitsh; 34) village of Otkhara, Otkharskaya Cave, $\sim 20 \mathrm{~m}$ from entrance, 23.07.2016, 1 specimen, A.G. Koval; 35) vicinity of the village of Otkhara, Abshdza (= P-1, Krasavitsa) Cave, $-300 \mathrm{~m}, 02.01 .2019,1$ specimen, N.L. Ivanov.

7. Pelophylax ridibundus (Pallas, 1771). In total, 5 specimens were recorded. Locations: 1) Russia, Krasnodarsky Krai, Sochi National Park: vicinity of the village of Kalezh (= Vtoroe Krasnoaleksandrovskoe), Krasnoaleksandrovskaya (= Ved'm, Dzhine and other names) Cave, in brook, 09.04.2007, 1 specimen, coll. S.B. Tuniyev (SNP, №1190); 2) vicinity of the village of Krasnaya Volya, Bochka Cave, -10 m, 02.10.2017, 1 specimen, R.S. Vargovitsh (Fig. 3C); 3) Abkhazia, Gudauta district: vicinity of the village of Blaburkhva, Akshasha (= Tsivi, Kholodnaya) Cave, a part of Mchishta-Akshasha Cave System, -25 m, Kvaksha Hall, 02.05.2015, 2 specimens, coll. N.O. Varlamov (SNP, №1193); 4) Gudauta district: vicinity of the village of Blaburkhva, Akshasha Cave, -25 m, Kvaksha Hall, 07.11.2015, 1 specimen, N.L. Ivanov; 5) Gudauta district: vicinity of the village of Blaburkhva, Akshasha Cave, -25 m, Kvaksha Hall, 05.05.2016, 1 specimen, coll. A.S. Bobunova (SNP, №1190). 

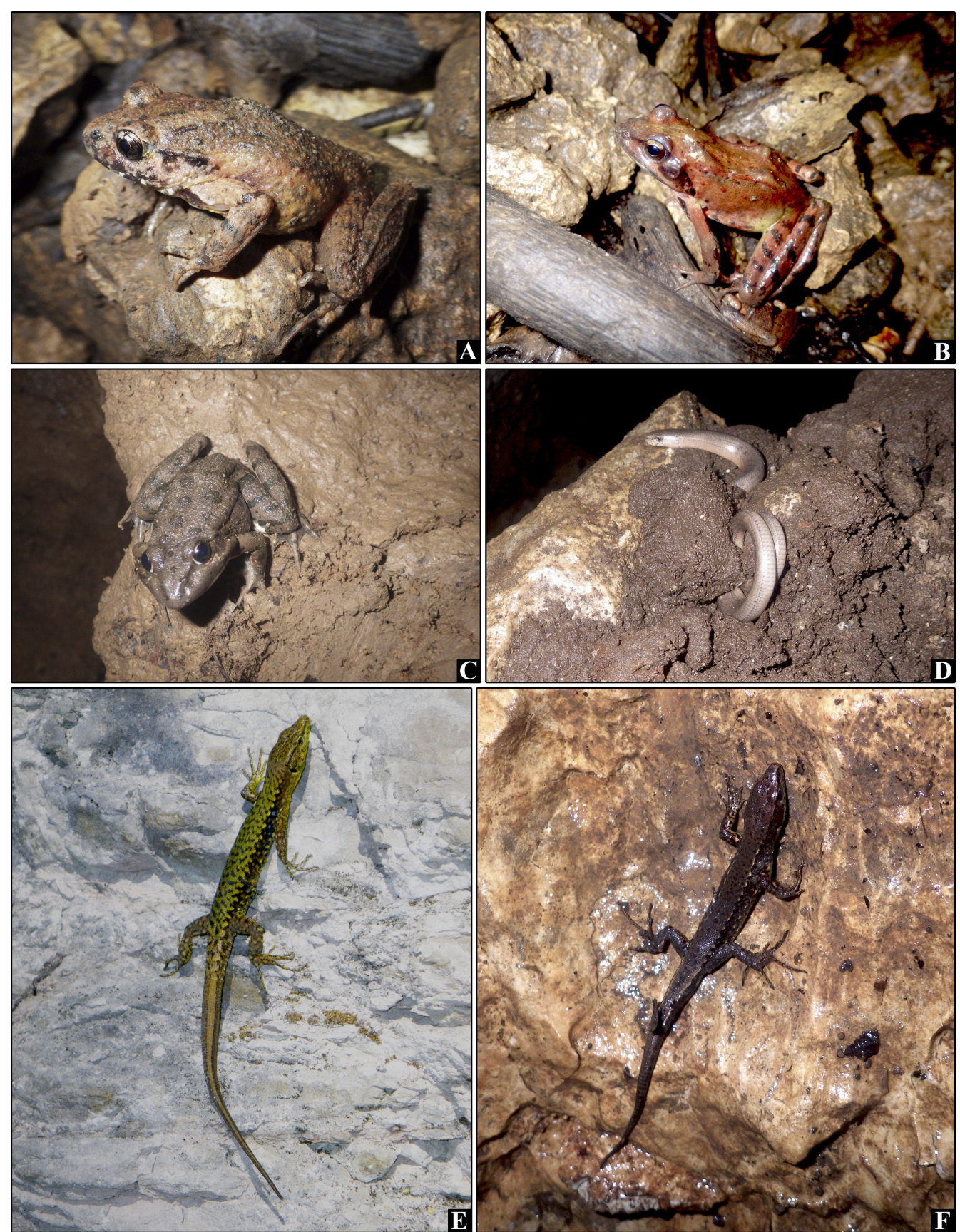

Fig. 3. Amphibians and reptiles in the Caucasian caves. Designations: A-Pelodytes caucasicus (Abkhazia, Marshania Verkhnyaya Cave) (Photo: R.S. Vargovitsh); B - Rana macrocnemis (Abkhazia, Marshania Verkhnyaya Cave) (Photo: R.S. Vargovitsh); C - Pelophylax ridibundus (Sochi National Park, Bochka Cave) (Photo: R.S. Vargovitsh); D - Anguis colchica (Abkhazia, Abkhazskikh Speleologov Cave) (Photo: R.S. Vargovitsh); E - Darevskia brauneri (Sochi National Park, Kolokolnaya Cave) (Photo: A.G. Koval); F - Darevskia derjugini (Abkhazia, Marshania Verkhnyaya Cave) (Photo: R.S. Vargovitsh).
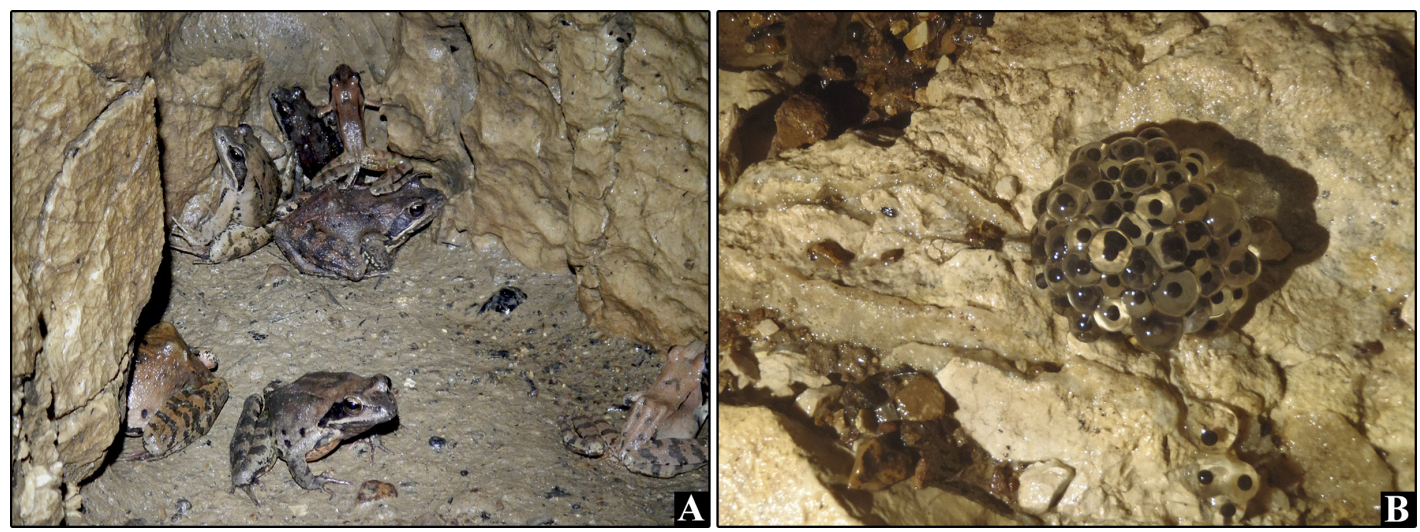

Fig. 4. Adults (A) (Photo: N.L. Ivanov) and eggs (B) (Photo: E.Yu. Snetkov) of Rana macrocnemis in Akshasha Cave (Abkhazia). 
Reptilia Laurenti, 1768

Order Sauria McCarthney, 1822

Family Anguidae Gray, 1825

8. Anguis colchica (Nordmann, 1840). In total, 15 specimens were recorded. Locations: 1) Russia, Krasnodarsky Krai, Sochi National Park: River Agura gorge, Chyortova Nora Cave, far end of Glavnaya Gallery, 27.08.1992, 1 specimen, A.G. Koval (Koval, 2004a); 2) Abkhazia, Ochamchira district: village of Otap, Golova Otapa Cave, near hall with bat colony, $\sim 150 \mathrm{~m}$ from lower entrance and not far from pit (-35 m), an upper entrance of this cave, 07.08.2010, 1 specimen, R.S. Vargovitsh, A.G. Koval; 3) vicinity of the village of Otap, Marshania Verkhnyaya (= Marshania II) Cave, on bottom of entrance pit, $-30 \mathrm{~m}$, 23.08.2015, 3 specimens, I.S. Turbanov; 4) vicinity of the village of Otap, Marshania Verkhnyaya Cave, on bottom of entrance pit, $-30 \mathrm{~m}, 30.06 .2016,1$ specimen, R.S. Vargovitsh; 5) vicinity of the village of Otap, Marshania Verkhnyaya Cave, on bottom of entrance pit, -30 m, 21.09.2017, 2 specimens, R.S. Vargovitsh; 6) vicinity of the village of Otap, Marshania Verkhnyaya Cave, on bottom of entrance pit, $-30 \mathrm{~m}$, 19.09.2018, 1 specimen, R.S. Vargovitsh; 7) village of Otap, Nad Golovoy Otapa Cave (= Uapatakhy Shaft), on bottom of entrance pit, -35 m, 28.06.2016, 1 specimen, R.S. Vargovitsh; 8) vicinity of the village of Aymara, Kotsha Cave, -25 m, 22.09.2017, 1 specimen, R.S. Vargovitsh; 9) Gudauta district: vicinity of Novy Afon town, left side of River Psyrtskha gorge, Abkhazskikh Speleologov (= Akuyu, Akuya) Cave, $-40 \mathrm{~m}$, on a shelf in lower part of ledge, 10.09.2015, 1 specimen, I.S. Turbanov; 10) Gudauta district: vicinity of Novy Afon town, left side of River Psyrtskha gorge, Abkhazskikh Speleologov Cave, 18.07.2016, 1 specimen, R.S. Vargovitsh (Fig. 3D); 11) vicinity of Novy Afon town, right side of River Psyrtskha gorge, Maanikvarskaya (= Maly Proval) Cave, on bottom of entrance pit, -70 m, 18.09.2017, 2 specimens, R.S. Vargovitsh.

\section{Family Lacertidae Bonaparte, 1831}

9. Darevskia brauneri (Mehely, 1909). In total, 24 specimens were recorded. Locations: 1) Russia, Krasnodarsky Krai, Sochi National Park: vicinity of the village of Krasnaya Volya, at top of right side of River Kudepsta gorge, Shirokopokosskaya (= Bozhiey Materi, Our Lady) Cave, near entrance, 31.08.2010, 5 specimens, A.G. Koval, R.S. Vargovitsh; 2) vicinity of the village of Krasnaya Volya, at top of left side of River Kudepsta gorge, Kolokolnaya Cave, near entrance, 05.09.2011, 2 specimens, A.G. Koval (Fig. 3E), R.S. Vargovitsh; 3) right side of River Ats canyon, Atsinskaya Cave, near entrance, 28.08.2013, 3 specimens, A.G. Koval, R.S. Vargovitsh; 4) right side of River Ats canyon, Atsinskaya Cave, near entrance, 18.09.2015, 2 specimens, A.G. Koval, R.S. Vargovitsh; 5) vicinity of the village of Kazachiy Brod, at top of right side of River Mzymta gorge, Malaya Kazachebrodskaya Cave, near entrance, 15.08.1996, 2 specimens, A.G. Koval; 6) vicinity of the village of Kazachiy Brod, at top of right side of River Mzymta gorge, Malaya Kazachebrodskaya Cave, near entrance, 14.08.1997, 1 specimen, A.G. Koval; 7) vicinity of the village of Kazachiy Brod, at top of right side of River Mzymta gorge, Malaya Kazachebrodskaya Cave, near entrance, 12.07.2015, 2 specimens, A.G. Koval; 8) vicinity of the village of Kazachiy Brod, at top of right side of River Mzymta gorge, Bolshaya Kazachebrodskaya (= Akhshtyrskaya) Cave, near entrance, 15.08.1996, 3 specimens, A.G. Koval; 9) vicinity of the village of Kazachiy Brod, at top of right side of River Mzymta gorge, Bolshaya Kazachebrodskaya Cave, 14.08.1997, 40-50 m from entrance, 4 specimens, A.G. Koval.

10. Darevskia derjugini (Nikolsky, 1898). In total, 5 specimens were recorded. Locations: 1) Abkhazia, Ochamchira district: village of Otap, Golova Otapa Cave, near hall with bat colony, $\sim 150 \mathrm{~m}$ from lower entrance and not far from pit $(-35 \mathrm{~m})$, an upper entrance of this cave, 21.09.2018, 1 specimen, A.G. Koval; 2) vicinity of the village of Otap, Marshania Verkhnyaya (= Marshania II) Cave, on wall of pit, -12 m, 30.06.2016, 1 specimen, coll. R.S. Vargovitsh (SNP, №1780) (Fig. 3F); 3) vicinity of the village of Aymara, Kotsha Cave, -20 m, 22.09.2017, 2 specimens (including 1 juvenile and 1 dead specimen), coll. R.S. Vargovitsh (SNP, №1781, 1 specimen); 4) vicinity of the village of Aymara, Kotsha Cave, -20 m, 21.09.2018, 1 specimen, R.S. Vargovitsh.

According to our data, amphibians and reptiles were found in less than $50 \%$ of the total number of surveyed caves, located up to $1300 \mathrm{~m}$ a.s.l. As a rule, herpetofauna representatives in the Greater Caucasus caves are quite rare and only single or few individuals are usually found. The exceptions are four caves: Fyodorovskaya Cave (vicinity of the city of Sochi), and Akshasha Cave, Abshdza Cave and Marshania Verkhnyaya Cave (all - Abkhazia).

Fyodorovskaya Cave (extent: 280 m, depth: -196 $\mathrm{m})$. The entrance to the cave is located in the central part of the West Akhtsu Ridge (Sochi National Park). The cave begins with two well-washed pits connecting at a depth of $-50 \mathrm{~m}$. At $-90 \mathrm{~m}$, the entrance pit goes 
into a cascade of inner cavities. At -115-120 m, a large Golikova Hall is located (Klimenko et al., 1991).

In this cave at a depth of $-94 \mathrm{~m}$, on a stone shelf (two-stage ledge with a total area of $6 \mathrm{~m}^{2}$ ) on 21.08.2011, St. Petersburg's speleologists found 12 specimens of three amphibian species (one specimen of Bufo verrucosissimus, one specimen of $\mathrm{Om}$ matotriton ophryticus, and ten specimens of Pelodytes caucasicus). One year before (17.08.2010), two specimens of $P$. caucasicus were recorded in the same cave. The entrance pit of this cave is an extended water crack. There are numerous narrow cracks and other karst formations throughout its length. The walls of the pit are not strictly vertical and quite sloping in some places, facilitating the penetration of amphibians. The cave has a second course, not explored because of the narrowness. This, presumably, leads either directly to the Golikova Hall, or to its second floor. Probably, most of the amphibians enter this place not through the pit, but through a system of cracks, ponors, and passages which are not passable for humans. In the specified location (on the shelf), the light is not visible, as the pit has a slight turn. At the site of the detection of amphibians, dripping water is quite intense and constant.

Marshania Verkhnyaya Cave (= Marshania II) is located in the forest at $470 \mathrm{~m}$ a.s.1., near the village of Otap (Ochamchira district, Abkhazia). This cave is about $-30 \mathrm{~m}$ vertical pit, slightly tilted, with a small subhorizontal extension at the bottom. The cave is not yet described in the literature and is named after the Abkhazian surname, the bearers of which live near it.

The cave was visited four times. On 23.08.2015, at the bottom of the cave, 14 specimens of four amphibian and one reptile species were found, including one specimen of Ommatotriton ophryticus, six Rana macrocnemis, three Pelodytes caucasicus, one Bufo verrucosissimus, and three Anguis colchica. On 30.06.2016, six specimens of five species of amphi-bians and reptiles were registered, including one specimen of Rana macrocnemis, two Pelodytes caucasicus, one Bufo verrucosissimus, one Anguis colchica, and one Darevskia derjugini (on the cave wall). On 21.09.2017, five specimens of Pelodytes caucasicus and two specimens of $\mathrm{Om}$ matotriton ophryticus were found. On 19.09.2018, 12 specimens of five species were recorded, including eight specimens of Pelodytes caucasicus, one Rana macrocnemis, one Bufo verrucosissimus, one Anguis colchica and one Ommatotriton ophryticus. Thus, 46 specimens of six species were recorded in the cave during four years. This abundance is because apparently the cave serves as a large natural trap. All amphibians and reptiles were brought to the surface and released.

Akshasha Cave (= Tsivi, Kholodnaya) (extent: $622 \mathrm{~m}$, depth: $-166 \mathrm{~m}$ ) is a part of the MchishtaAkshasha Cave System. The entrance to Akshasha Cave is located near the village of Blaburkhva in the Gudauta district of Abkhazia.

All the amphibians were found in the Kvaksha Hall of this cave, located at a depth of $-25 \mathrm{~m}$ from the entrance. For the first time, Moscow's cavers entered this hall in May 2003, after the expansion of the passage. Frogs were already there. Hence, this hall got the appropriate name («kvaksha» is translated as a tree frog). It remains unknown how frogs penetrate the Kvaksha Hall, i.e. through the main course, in which the cavers descend, or through various cracks and ponors, inaccessible to human. Both options are possible, according to an oral communication of speleologist N.L. Ivanov (Moscow, Russia). Thus, in February 2017, one specimen, believed to be Rana macrocnemis, was found in this cave at a depth of $-160 \mathrm{~m}$ in a creek. To get there, the animal had to pass several cave pits and other obstacles. The penetration and temporary habitat of amphibians in caves are facilitated by factors such as high humidity, temperature, and poor light, as well as stress occurring periodically in terrestrial biotopes (Lunghi et al., 2017).

In the Kvaksha Hall, speleologists from Moscow and other cities, recorded and observed the frogs from May 2015 to May 2017. Sixty-three specimens of tailless amphibians were registered there. The vast majority of them were Rana macrocnemis (59 specimens, or $93.6 \%$ of the total number of ones). Besides, two Hyla orientalis specimens and two Pelophylax ridibundus specimens were found in the same hall. The Rana macrocnemis females laid eggs on the stones and stoneflows (Fig. 4B). In the Kvaksha Hall, there are small water puddles. However, because speleologists did not visit this cave in the second half of May and in summer, it remains unknown whether the frogs developed from these laid eggs. For two-year observations, a decreasing trend in the number of frogs in the Kvaksha Hall was noted. Thus, 32 specimens were noted on 02.05.2015, 17 specimens in early November 2015, 12 specimens on 06.01.2016, and two specimens on 05.05.2016. When this hall was visited in January, February, and May 2017, frogs were absent. According to N.L. Ivanov (personal communication) (Moscow, Russia), their disappearance could be caused by a rat penetration into the Kvaksha Hall. However, escaping the cave by frogs cannot be excluded.

Abshdza Cave (= P-1, Krasavitsa) (extent: 2200 
m, depth: $-375 \mathrm{~m}$, altitude: $370 \mathrm{~m}$ a.s.1., according to oral communication of N.L. Ivanov, Moscow, Russia) is located on the southern macroslope of the Bzyb Mountain Range, in the vicinity of the village of Otkhara (Gudauta district, Abkhazia). The cave has a series of pits, ledges and narrow cavities, ending with subhorizontal part and siphons. The latter appear to have a hydrological connection to the Mchishta-Akshasha Cave System, which is located close to Abshdza Cave.

In November 2017-2019 and in January and May 2019, the speleologists from Moscow, Novosibirsk, and Perm noted 17 Hyla orientalis specimens on the way from the entrance to one of the siphons $(-310 \mathrm{~m})$. In addition, a Rana macrocnemis specimen was observed in this cave at a depth of $-300 \mathrm{~m}$ in January 2019.

\section{Discussion}

Jeannel (1943) found that only some aquatic vertebrates are real cavernicolous species (fishes and tailed amphibians). This view is confirmed by others (e.g. Durand, 1998; Raffaelli, 2013). It is pointed out that the tailless amphibians found in the caves are only random cave dwellers - trogloxenes, and troglophilic tailless amphibians are known mainly from the caves of the tropics (Durand, 1998).

Reports of amphibians from subterranean habitats usually concern Proteus anguinus Laurenti, 1768 and salamanders (Arnold \& Burton, 1978; Engelmann et al., 1985; Raffaelli, 2013; Glandt, 2015). In the Caucasian ecoregion, troglophilic amphibians are cave salamanders, Iranodon persicus (Eiselt \& Steiner, 1970), from the Elburz Mountain Range (Eiselt \& Steiner, 1970; Ahmadzadeh et al., 2011; Raffaelli, 2013), while Mioproteus is known only in fossil condition. Mioproteus caucasicus Estes \& Darevsky, 1977 was found in Miocene sediments in the North-West Caucasus (Estes \& Darevsky, 1977). The earliest find is known from the Middle Miocene of Central Kazakhstan (Malakhov, 2003). Later this phossylous species was found in southern Germany (Durand, 1998). It should be noted that Mioproteus caucasicus was found in the MidSarmatian sediments of the River Belaya near Maykop (Adygheya). The River Belaya source is located on the large alpine karst Fisht-Oshten massif, teeming with caves and large vaucluses pouring underground rivers to the surface. These underground watered cavities remain uninvestigated, and the discovery of phossylous Mioproteus caucasicus Estes et Darevsky 1978 could be associated with its removal from underground streams. While Malakhov (2003) wrote against the suggestion that Mioproteus was a troglodytic animal because Kazakh (Ashut) locality has not any significant mountains nearby.

In this regard, it is worth listing a small phossylous material on amphibians from the caves of the Greater Caucasus. According to Baryshnikov (2012), several small frog bones (Rana sp.) have been found in the Pleistocene layers of Akhshtyrskaya (Bolshaya Kazachebrodskaya) Cave. Bufotes viridis (Laurenti, 1768) was mentioned from this cave later (Syromyatnikova et al., 2017). Pleistocene remnants of Bufo verrucosissimus are known from various districts of Colchis: in Abkhazia - Kholodny Grotto and Kep-Bogaz (= Apiancha) Grotto, in Guria (Georgia) - Belaya Cave (Bakradze \& Chkhikvadze, 1984; Chkhikvadze, 1984). Bones of two Late Pleistocene amphibian species (Rana macrocnemis and Bufo sp.) were found in Mezmaiskaya Cave (Krasnodarsky Krai) (Syromyatnikova et al., 2013, 2017), and bones of Rana sp. were registered in Matuzka Cave (Syromyatnikova et al., 2017). Besides, in South Ossetia the remains of amphibians (Rana sp., Bufo sp.) from Kudaro I Cave (Darevsky, 1980; Chkhikvadze, 1984; Zerova \& Chkhikvadze, 1984; Roček, 1993) and remains of amphibians (Rana macrocnemis, Pelophylax ridibundus and Bufotes viridis) from Kudaro III (Amiranashvili et al., 1991) are of great interest. In North Ossetia, the Pleistocene remains of Rana sp. and Bufotes viridis are known from Myshtulagty Lagat (Laski) Cave (Syromyatnikova et al., 2017). It follows from these data that tailless amphibians occurred in the Caucasian caves in past geological epochs.

Tailless amphibians might sometimes be found in caves or other underground habitats. But unlike salamanders, their reproduction in caves or similar subterranean habitats in Western Europe has never been recorded. The reproduction of Rana iberica Boulenger, 1879 was noted in the underground drainage gallery in Portugal, observed from May 2010 to December 2012. It is the first report of the frog breeding in the underground habitat of Western Europe (Rosa \& Penado, 2013). The authors attribute this changed behaviour of the species with the increase in the climate aridity (aridisation) in the Mediterranean and the Iberian Peninsula in recent years. According to Rosa \& Penado (2013), underground habitats, including artificial ones, can serve as shelters for the survival of some amphibians in the face of climate change.

According to Zagorodniuk \& Petrushenko (2003), the main factor forcing amphibians to enter the caves is their seasonal migrations from the places of summer activity to wintering places, which 
ease penetration of amphibians into caves. At the same time, they are often registered in vertical or subhorizontal caves with a vertical entrance. In such caves, amphibians and reptiles can be brought in by water, or accidentally fall into them, therefore these caves are «natural traps» for them (Zagorodniuk \& Petrushenko, 2003). Thus, the information about the Rana macrocnemis presence in the well-known Novoafonskaya Cave (Kapralov, 2017), in our opinion, is exactly the case, because Anakopia Hall (formerly is Abkhazia Hall) is connected with the surface of the earth by a natural shaft of $142 \mathrm{~m}$ depth. This entrance shaft is rather not a strict smooth-walled vertical, but looks like a steep spiral extended at the top, with ledges and sloping passages.

In 1990s-2000s we observed the accumulation of wintering adults of Salamandra salamandra Linnaeus, 1758(upto35 specimens)intheunderground cavities of the Ukrainian Carpathians, located near the town of Mukachevo (Turbanov et al., 2019). Also their larvae were regularly observed, for several years, in a semi-submerged adit in vicinity of the village of Hlyboke near Uzhgorod, which indicates the apparent propensity of this species to troglophily. We recorded a probable wintering of a large Natrix natrix Linnaeus, 1758 specimen in the early-spring period in the adit near Mukachevo, at a distance of $25 \mathrm{~m}$ from the entrance. We also regularly noted 3-5 living specimens of Lissotriton montandoni Boulenger, 1880 in a hall under the $21 \mathrm{~m}$ entrance pit of Druzhba Cave in the Ukrainian Carpathians. They were in good condition, but possibly accidentally fell there from the surface.

Probably, some part of the Greater Caucasian amphibians and reptiles enter the caves purposefully for wintering under adverse climatic conditions, and for feeding. Such penetration occurs both through the main wide passages of caves, and through the system of narrow cracks and ponors, inaccessible to humans. The other part occurs in the caves (especially at the bottom of vertical pits) by accident, becoming «prisoners of circumstances». However, in terms of life expectancy, changes in colouration (lighting of the main pigmentation), and good external condition of many individuals, these amphibians can be considered as subtroglophiles. Similar assumptions about the possibility of long-term existence of amphibians and reptiles in caves are also indicated for the Mediterranean. For example, in Pazinska Jama Cave in Croatia (Koller, 2017), Bufo bufo Linnaeus, 1758 and Emys orbicularis Linnaeus, 1758 were lighter in colour than usually. In the Caucasus, the egg-laying of Rana macrocnemis in Akshasha Cave confirms the possibility of breeding in the caves in this case, when the species can be considered as prone to eutroglophily or as a transition from subto eutroglophily (Sket, 2008, and see above). This was also confirmed for the closely related species Rana iberica in Portugal (Rosa \& Penado, 2013) and presumed for another close species Rana latastei Boulenger, 1879 in Croatia (Koller, 2017).

Troglobiont reptiles are unknown worldwide yet. But some species are regularly found in tropical caves, which they use as shelter from the heat, for hibernation, reproduction, or molting. For example, such reptiles can also feed on bats and birds in underground cavities (Decu et al., 1998; Martin-Solano et al., 2016). Similar observations were carried out in the Crimea. In this region, Mediodactylus kotschyi danilewskii (Strauch, 1887) and Zamenis situla (Linnaeus, 1758) have been observed in small warm caves while wintering, as well as seeking for shelter at other periods of the year, and sometimes looking for food (Turbanov et al., 2015, 2019).

The caves of the foothills, where the vast majority of amphibians and reptiles are observed, are usually characterised by a rich faunal diversity. For example, Chyortova Nora Cave is inhabited by 35 species of animals, including 29 arthropod species of Arachnida, Myriapoda, Crustacea, and Insecta. In this cave, 18 insect species belong to Coleoptera, Diptera, Orthoptera and Plecoptera. Also, in the cave there are numerous molluscs (Koval, 2004a). The fauna of Akhunskaya Cave is even more abundant. Forty-eight species of animals have been found here, including 43 arthropod species. Of them, 27 species are insects. There are also two molluscs and one earthworm (Lumbricidae) (Koval, 2004b). Terrestrial Isopoda occur in both studied caves, as well as aquatic Amphipoda. While being in caves, amphibians and reptiles can prey most of these groups of invertebrates.

In caves of the Greater Caucasus, the fossil material of reptiles is also small. Testudo graeca Linnaeus, 1758 was found in Belaya Cave (Georgia) near the town Tskhaltubo (Vekua et al., 1979) and from the Pleistocene graves of Gienovaya Cave (Alekperov, 1978). Lacerta sp., like Lacerta agilis Linnaeus, 1758 are known from Kudaro I Cave in South Ossetia (Darevsky, 1980; Chkhikvadze, 1984; Zerova \& Chkhikvadze, 1984; Roček, 1993). Emys orbicularis Linnaeus, 1758 is known from Kudaro III Cave (Baryshnikov \& Nesov, 1999). Several small bones of Lacerta sp. and Anguis fragilis (= A. colchica) (Baryshnikov, 2012; Syromyatnikova et al., 2017) were found in the Pleistocene layers of 
Akhshtyrskaya (Bolshaya Kazachebrodskaya) Cave in Sochi National Park. Bones of Late Pleistocene reptile species (Anguis fragilis, Lacerta agilis, Darevskia sp., Coronella austiaca Laurenti, 1768, Viperidae indet.) were found in Mezmaiskaya Cave (Krasnodarsky Krai) (Syromyatnikova et al., 2013), and bones of Lacertidae indet. and Coronella austriaca were registered in Matuzka Cave (Syromyatnikova et al., 2017).

Concerning the species found in the caves of the Greater Caucasus, Ommatotriton ophryticus is infrequently found exclusively in vertical caves and usually presented by single specimens in the bottom part or on stone ledges. The specimen from Kelasurskaya Cave, in the bottom part of the river flows, has a relatively light colouration (Fig. 2A), probably due to its extended stay in the subterranean environment. All the individuals we examined had no signs of exhaustion, indicating their nutrition in the underground cavities. We cannot assess the status of animals at the time of falling into the caves. Still, a skin structure of all the specimens, observed at the time of the find, corresponded to that in the terrestrial phase of life, outside the breeding period. Ommatotriton ophryticus is usually found in caves located near terrestrial breeding ponds. Thus, Canyon Cave on the Chernogor Plateau is located next to the Cheshe Lake, which is home to one of the largest group of $O$. ophryticus, numbering more than 1000 mature individuals (Tuniyev \& Tuniyev, 2007a).

Bufo verrucosissimus is relatively common in caves. The species was usually found in the entrance parts of the caves, or at the bottom and ledges of the entrance pits (shafts). Exceptions are the records at a depth of $100 \mathrm{~m}$ in Gigantov Cave (vicinity of the city of Sochi, Alek Ridge) and at a depth of $130 \mathrm{~m}$ and at about $600 \mathrm{~m}$ from the entrance in Pechalnaya Cave (vicinity of the city of Sochi, Dzykhra Ridge). In Vorontsovskaya Cave (vicinity of the city of Sochi, Vorontsovsky Ridge), Bufo verrucosissimus was found at $200 \mathrm{~m}$ from the entrance (Tuniyev \& Tuniyev, 2007b). Another B. verrucosissimus specimen was recorded in Verkhnyaya Shakuranskaya Cave in Abkhazia, at about $500 \mathrm{~m}$ from the entrance at the stream flowing through this subhorizontal cave. The largest Caucasian amphibian Bufo verrucosissimus requires much food to maintain healthy conditions. It should be noted that most of the toads observed were normally nourished. In contrast, individuals in Marshania Verkhnyaya Cave were depleted, due to the relatively large number of amphibians and reptiles of different species entering this «trap» pit (see above) and the emerging competition for limited cave food.
Hyla orientalis was mentioned rather rarely in the Caucasian caves. With the ability to climb vertical surfaces, they can probably escape the cave, even if they accidentally get there. This ability, as well as floods, allows them to penetrate very deep cave parts. Thus, according to the oral communication of N.L. Ivanov (Moscow, Russia), Hyla orientalis was observed in the late 1970s in Zabludshikh Cave (vicinity of the city of Sochi, Alek Ridge) at a depth of $\sim 300 \mathrm{~m}$. Several pits had to be passed to reach this site. The latest records made in 2018 and 2019 in Abshdza Cave (Abkhazia) confirmed the possibility of penetration of $H$. orientalis into quite remote parts of the caves. The species was observed here at different depths (see above), e.g. in early January 2019 one individual was discovered far from the entrance, at a depth of $310 \mathrm{~m}$. To reach this place, the animal had to pass long vertical and horizontal areas. According to N.L. Ivanov's observation, in November 2018, Hyla orientalis very quickly climbed up the rope at a depth of $250 \mathrm{~m}$ in Abshdza Cave. In May and November 2019, specimens of this species were also observed at different depths (from -10 m to -250 m) of this complex cave.

Hyla savignyi is a new species for the fauna of Abkhazia and the West Caucasus in general. The known distribution area covers the southern arid regions of Southern Armenia and Azerbaijan, as well as Iran, Eastern Turkey, Iraq, and Northern Arabia in the south. Previously, this species was found by us in Pitsunda (Western Abkhazia) but was identified as the anomalous aberration of Hyla arborea shelkownikowi $(=H$. orientalis Bedriaga, 1890) (Tuniyev, 2017). In addition to the specimen mentioned earlier from Samshitovaya Cave (SNP, №1185, Abkhazia, Ochamchira district, village of Otap (Uatap), spurs of Kodor Mountain Range, Samshitovaya Cave, at a depth of $20 \mathrm{~m}$, 21.08.2015, coll. I.S. Turbanov), a specimen, caught on the surface in the village of Otap (SNP, №1192, Abkhazia, Ochamchira district, vicinity of the village of Otap, spurs of Kodor Mountain Range, 300 m a.s.1., 27.06.2016, coll. A.G. Koval) was also examined. Finding of this South-FrontalAsian species in Abkhazia is extremely interesting in terms of its biogeographical position. However, despite its phenomenality, it is not nonsense, because it complements the well-known for Abkhazia series of faunal and floral finds of the species common in the south of Frontal Asia, mostly in the FrontalAsian sector of the Eastern Mediterranean. Thus, Lacerta strigata Eichwald, 1831 was found on the Cape Pitsunda (Rudik, 1986). On this location and 
in the lower flow of the River Psou in the vicinity of the village of Salme (= Psou), Lacerta media Lantz \& Cyren, 1920 was found (Tuniyev, 1995). Being common in the Mediterranean region, Erica arborea L. grows on the Kavakluk (Myussera) Hills here, and additionally on the rocks at the River Gega mouth in Ritsa Relic National Park, there is Arbutus andrachne L. known in the Eastern Mediterranean, the Artvin Depression of the River Chorokh in Turkey, on the rocks of the River Adzharistskali in Georgia and on the Southern Coast of the Crimea (Aliev et al., 2020). The list of native plants from the Mediterranean in a broad sense can be enlarged in many times. It is no coincidence that Kolakovsky (1980) singled out the narrow seaside strip of Abkhazia as an integral part of the Mediterranean biogeographical region. A stretch of coastline from Anapa to Sukhum was incorporated by Tuniyev (1995) into the Black Sea refugium of the East Mediterranean herpetofauna. Obviously, we see the fading elements of the former hemixerophilous landscapes, which have found the conditions for widespread development along the Black Sea Coast of the Caucasus in the Holocene and the islets preserved in the heart of Colchis at present. The find of Hyla savignyi in Abkhazia should be attributed to these relict elements of hemixerophilous fauna.

Pelodytes caucasicus is relatively often recorded in the entrances of horizontal caves, or at the bottom and on the ledges of the entrance parts of vertical caves. The exception is the find of three Pelodytes caucasicus individuals together with a Bufo verrucosissimus individual (see above) in Pechalnaya Cave at a depth of $130 \mathrm{~m}$. The specimens of $P$. caucasicus and $B$. verrucosissimus most probably reached this place not through the main course with many wells and ledges, but through some cracks and ponors, inaccessible to a human. Pelodytes caucasicus has a burrowing lifestyle. This feature of its biology is associated with good external condition of animals in caves, without visible signs of exhaustion. However, P. caucasicus from Marshania Verkhnyaya Cave had a common background lightening, or erythrism, not found in specimens from terrestrial habitats.

Rana macrocnemis is the most abundant species in the caves of the Greater Caucasus $(39.0 \%$ of all amphibians and reptiles). This species is found both in the entrance and in the distant parts of the caves. For example, in Kabardino-Balkaria, in Omega-15 (NSS-53) Cave, R. macrocnemis specimens were recorded in a stream at a distance of 400-500 $\mathrm{m}$ from the lower entrance. In Labirintovaya Cave (part of the Vorontsovskaya Cave System, in the vicinity of the city of Sochi), $R$. macrocnemis was discovered at a distance of $700 \mathrm{~m}$ from the cave entrance. In early January 2019, one of Rana macrocnemis specimens was found in the remote part of Abshdza Cave (Abkhazia) at a depth of $300 \mathrm{~m}$. A part of the found specimens were in good condition, while others were severely emaciated, in particular, in Marshania Verkhnyaya Cave, due to the relatively large number of various amphibian species entering the pit (see above) and the emerging competition for limited cave food. Besides, a specimen from Nyvdzhin Lagat Cave (North Ossetia-Alania) had a very bright red colouration (erythrism). As noted above, $R$. macrocnemis occurring in caves during the breeding season can lay eggs on wet stones and underground watercourses.

In the caves of the Greater Caucasus, Pelophylax ridibundus is rare, because of habitat preferences of this species to river valleys and standing water bodies (Tuniyev \& Tuniyev, 2006a) usually absent on karst massifs. Pelophylax ridibundus was found in Abkhazia in the near entrance part of Akshasha Cave (part of the Mchishta-Akshasha Cave System) at a depth of $25 \mathrm{~m}$ and in Sochi National Park in Bochka Cave, at a depth of $10 \mathrm{~m}$.

Anguis colchica is rare in caves. The animals got there, apparently by accident, falling into the entrance pits, ponors and other vertical parts of the caves. In the relatively warm horizontal Chyortova Nora Cave (Sochi National Park) with air temperature from $13^{\circ} \mathrm{C}$ to $15.5^{\circ} \mathrm{C}$ in the far part, and from $14^{\circ} \mathrm{C}$ to $20^{\circ} \mathrm{C}$ in the near part, the Anguis colchica, probably got inside through one of its ponors (Koval, 2004a). Anguis colchica from Golova Otapa Cave (Abkhazia), judging by the injuries of the body, fell into the entrance pit.

Darevskia brauneri and D. derjugini are known mainly from the parts of caves closest to the entrance (not farther than $50 \mathrm{~m}$ ), where light penetrates and where the temperature is still relatively high. We did not note any changes in the lizard cover structure, such as reducing the ribbing of scales, which would indicate their specialisation in cave habitats, as reported for some geckos from caves in the $\mathrm{Za}$ gros Mountains, Iran (Esmaieli-Rineh et al., 2016). In addition to the caves mentioned above, Darevskia brauneri was observed at the entrances of many caves in Sochi National Park and Abkhazia. We deliberately did not expand the list of caves, as these observations had nothing to do with the cave finds.

\section{Conclusions}

Summing up, we recorded 272 specimens of amphibians and reptiles belonging to ten species 
(including seven amphibians and three reptiles) in 61 caves of the Greater Caucasus. They were found in less than $50 \%$ of the total number of surveyed caves, which are located at altitudes up to $1300 \mathrm{~m}$ a.s.l. In the four caves mentioned above (Fyodorovskaya, Akshasha, Abshdza, Marshania Verkhnyaya), 141 specimens of amphibians and reptiles were observed, i.e. more than half $(51.8 \%)$ of the specimens recorded in the caves of the Greater Caucasus. They belong to eight species ( $80.0 \%$ of all species found). In general, for all the cases studied, the most considerable proportion of the total abundance refers to Rana macrocnemis (39.0\%), Pelodytes caucasicus (17.3\%), Bufo verrucosissimus (11.0\%), Darevskia brauneri (8.8\%), Hyla orientalis $(8.1 \%)$. These five species represent $84.2 \%$ of all amphibians and reptiles found in caves in the Greater Caucasus. The total proportion of the remaining five species (i.e. Ommatotriton ophryticus, Hyla savignyi, Pelophylax ridibundus, Anguis colchica and Darevskia derjugini) is $15.8 \%$. Such species as Ommatotriton ophryticus, Hyla orientalis, $H$. savignyi, Pelophylax ridibundus, Anguis colchica are trogloxenes. Bufo verrucosissimus, Pelodytes caucasicus, Darevskia brauneri and Darevskia derjugini are subtroglophiles. Rana macrocnemis shows a penchant for eutroglophily.

\section{Acknowledgments}

The authors express sincere gratitude to Igor A. Belousov, Olga A. Inozemtseva, Veronika A. Gulymanova, Yuriy S. Lipchenko, Kim B. Sedov, Anna M. Sedova (Karpova), Oleg A. Petrov, Valentin V. Rystsov, Dmitriy S. Vakhromov (Russia, Saint Petersburg); Anna S. Bobunova, Nikolay L. Ivanov, Evgeniy Yu. Snetkov (Russia, Moscow); Kirill V. Bagriy (Russia, Moscow Region, Korolyov); Svetlana A. Bogdanenko, Evgeniy A. Romanov (Russia, Sevastopol); Nadezhda V. Grishina, Ekaterina F. Doni, Evgeniy V. Zakharov, Nadezhda V. Kolmakova, Oleg O. Lesnevskiy, Oleg V. Merkuriev, Natalya V. Muzalevskaya, Igor N. Pelkin, Mikhail N. Prokopiev, Alexander A. Solntsev, Andrey A. Chumachkov, Alexey V. Shishimorov, Sergey V. Yashin (Russia, Sochi); Vasiliy A. Makukhin (Russia, Rostov-on-Don); Galina V. Lezhnina (Russia, Tomsk); Irina A. Drachkova (Russia, Novosibirsk); Ilya S. Turbanov (Russia, Yaroslavl Region, Borok); Nikita O. Varlamov (Russia, Samara Region, Tolyatti); Oleg A. Kholodnyak (Russia, Perm); Sergey Yu. Lipchenko (Russia, Karachay-Cherkessia, Cherkessk); Ruslan A. Tavasiev (Russia, North Ossetia-Alania, Vladikavkaz); Anatoliy V. Shamray (Russia, Kabardino-Balkaria, Nalchik); Roman S. Dbar (Abkhazia, Sukhum); the families of Indiko D. Adleyba and Mukhran A. Marshania (Abkhazia, Otap); Mirab V. Inapshba (Kotsha) (Abkhazia, Aymara); Roman S. Gezerdava (Abkhazia, Bacha); Valeriy V. Markholia (Abkhazia, Novy Afon); Suren V. Gazaryan (Germany, Bonn), and many others for their help in collecting, photographing and counting herpetofauna representatives in the caves and other assistance that contributed to preparation of this study.

\section{References}

Ahmadzadeh F., Khanjani F., Shadkam A., Böhme W. 2011. A new record of the Persian Brook Salamander, Paradactylodon persicus (Eiselt \& Steiner, 1970) (Amphibia: Caudata: Hynobiidae) in northern Iran. Bonn zoological Bulletin 60(1): 63-65.

Alekperov A.M. 1978. Amphibians and reptiles of Azerbaijan. Baku: Elm. 262 p. [In Russian]

Aliev Kh.U., Tuniyev B.S., Timukhin I.N., Taniya I.V. 2020. Geobotanical and population characteristics of Arbutus andrachne L. in Abkhazia. Bulletin of the State Nikitskiy Botanical Gardens 135: 24-38. DOI: 10.36305/05131634-2020-135-24-38 [In Russian]

Amiranashvili N.G., Gutieva N.V., Chkhikvadze V.M. 1991. New data on herpetofauna of Paleolithic of Georgia. In: I.G. Taktakashvili (Ed.): Flora and fauna of MezoCenozoic of Georgia. Tbilisi: Metsniereba. P. 159-165. [In Russian]

Arnold E.N., Burton J.A. 1978. A field guide to the reptiles and amphibians of Britain and Europe. London: Collins. 272 p.

Bakradze M.F., Chkhikvadze V.M. 1984. Fossil terrestrial turtles of genus Testudo in the USSR. Bulletin of the State Museum of Georgia 33A: 163-174. [In Russian]

Baryshnikov G.F. 2012. A review of fossil vertebrate remains from Pleistocene layers of Akhshtyrskaya Cave (NorthWest Caucasus). Proceedings of the Zoological Institute RAS 316(2): 93-138. [In Russian]

Baryshnikov G.F., Nesov G.F. 1999. About find of Emys orbicularis in Ashel fauna of Kudaro III Cave in the Transcaucasia. Proceedings of the Zoological Institute RAS 277: 127-129. [In Russian]

Chkhikvadze V.M. 1984. Overview of the fossil tailed and tailless amphibians of the USSR. Bulletin of the Academy of Sciences of Georgian SSR 10(1): 5-13. [In Russian]

Darevsky I.S. 1980. Amphibians and Reptiles from Kudaro I Cave. In: I.K. Ivanova, A.G. Chernyakhovsky (Eds.): Kudaro Cave paleolithic sites in South Ossetia. Moscow: Nauka. P. 125-127. [In Russian]

Decu V., Juberthie Ch., Andrei M.D. 1998. Reptilia. In: Ch. Juberthie, V. Decu (Eds.): Encyclopaedia biospeologica. Vol. 2. Moulis: [Laboratoire Souterrain]. Bucarest: Académie Roumanie. P. 1245-1247.

Durand J.P. 1998. Amphibia. In: Ch. Juberthie, V. Decu (Eds.): Encyclopaedia biospeologica. Vol. 2. Moulis: [Laboratoire Souterrain]. Bucarest: Académie Roumanie. P. 1215-1243.

Eiselt J., Steiner H.M. 1970. Erstfund eins hynobiiden Molches in Iran. Annalen des Naturhistorischen Museum in Wien 74: 77-90.

Engelmann W.-E., Fritzsche J., Günther R., Obst F.J. 1985. Lurche und Kriechtiere Europas. Leipzig; Radebeul: Newmann Verlag. 420 p.

Esmaieli-Rineh S., Akmali V., Fathipour F., Heidari N., Rastegar-Pouyani N. 2016. New distribution records of cave-dwelling gekkonid lizards (Sauria, Gekkonidae and Phyllodactylidae) in the Zagros Mountains of Iran. Subterranean Biology 18: 39-47. DOI: 10.3897/ subtbiol.19.8185 
Estes R., Darevsky I.S. 1977. Fossil amphibians from the Miocene of the North Caucasus, USSR. Journal of the Palaeontology Society of India 20: 164-169.

Glandt D. 2015. Die Amphibien und Reptilien Europas. Wiebelsheim: Quelle \& Meyer Verlag. 716 p.

Jeannel R. 1943. Les fossiles vivants des caverns. [S.1.]: Gallimand. $321 \mathrm{p}$.

Kapralov S.A. 2017. To the fauna of Novoafonskaya Cave, Abkhazia. In: Biospeleological research in Russia and adjacent countries. Yaroslavl: Filigran. P. 39-42. [In Russian]

Klimenko V.I., Rezvan V.D., Dublyansky V.N. 1991. Engineering and geological zoning of territory of the mountain limestone karst development to justify protective measures (on example of the region of Sochi). Methodical recommendations. Sochi. 116 p. [In Russian]

Kolakovsky A.A. 1980. Flora of Abkhazia. Vol. 1. Tbilisi: Metsniereba. 247 p. [In Russian]

Koller K. 2017. Underground occurrences of three species of amphibians and reptiles with special emphasis on Rana latastei (Amphibia: Anura). North-Western Journal of Zoology 13(1): 176-179.

Koval A.G. 2004a. To the knowledge of the fauna of Chyortova Nora Cave in the North-West Caucasus. In: M.Yu. Kalashian (Ed.): Proceedings of the Conference on Invertebrates' Zoology dedicated to the $100^{\text {th }}$ anniversary of S.M. Iablokoff-Khnzorian. Yerevan: Zoological Institute. P. 75-80. [In Russian]

Koval A.G. 2004b. To the knowledge of Akhunskaya Cave fauna of the North-West Caucasus. Peshchery 29/30: 150-155. [In Russian]

Krochko Yu.I. 1973. Fauna of vertebrates of some caves and subterraneans of the Zakarpatska Oblast. In: V.I. Komendar (Ed.): About nature protection of the Carpathians. Uzhgorod: Karpaty. P. 172-174. [In Ukrainian]

Kukushkin O.V., Petrov B.P., Nazarov R.A., Melnikov D.A. 2017. The problem of a biogeographical status of two reptiles with narrow distributions in the Crimea Mountains and the importance of Cape Aya karst caves for its solution. In: Biospeological research in Russia and adjacent countries. Yaroslavl: Filigran. P. 56-70. [In Russian]

Lunghi E., Manenti R., Ficetola G.F. 2017. Cave features, seasonality and subterranean distribution of non-obligate cave dwellers. PeerJ 5: e3169. DOI: 10.7717/peerj.3169

Malakhov D.V. 2003. The earliest known record of Mioproteus (Caudata; Proteidae) from the Middle Miocene of Central Kazakhstan. Biota 4(1/2): 67-72.

Martin-Solano S., Toulkeridis T., Addison A., Pozo-Rivera W.E. 2016. Predation of Desmodus rotundus Geoffroy, 1810 (Phyllostomidae, Chiroptera) by Epicrates cenchria (Linnaeus, 1758) (Boidae, Reptilia) in an Ecuadorian Cave. Subterranean Biology 19: 41-50. DOI: 10.3897/subtbiol.19.8731

Racovitza E.G. 1907. Essai sur les problèmes biospéologiques. Biospéologica I. Archives de zoologie expérimentale et générale. Série 4 6(7): 371-488.

Raffaelli J. 2013. Les Urodéles du monde. $2^{\text {nd }}$ ed. Plumelec: Penclen Edition. 480 p.
Roček Z. 1993. Holocene anurans from Caucasus. Asiatic Herpetological Research 5: 31-44.

Rosa G.M., Penado A. 2013. Rana iberica (Boulenger, 1879) goes underground: subterranean habitat usage and new insights on natural history. Subterranean Biology 11: 15-29. DOI: 10.3897/subtbiol.11.5170

Rudik A.M. 1986. About record of Lacerta strigata Eichwald in the Caucasian Black Sea Coast. Proceedings of the Zoological Institute RAS 158: 187-188. [In Russian]

Sket B. 2008. Can we agree on an ecological classification of subterranean animals? Journal of Natural History 42(2122): 1549-1563. DOI: 10.1080/00222930801995762

Syromyatnikova E.V., Doronin I.V., Baryshnikov G.F. 2013. The amphibian and reptilian remains from Mezmaiskaya Cave: new data on the late Pleistocene herpetofauna of the Caucasus. In: G.G. Matishov (Ed.): Fundamental problems of Quaternary, results and main trends of future studies. Rostov-on-Don: SSC RAS Publishers. P. 615-616. [In Russian]

Syromyatnikova E.V., Doronin I.V., Baryshnikov G.F. 2017. Pleistocene herpetofauna of the Caucasus. In: Yu.A. Lavrushin, F.V. Panin (Eds.): Fundamental problems of Quaternary, results and main trends of future studies. Moscow: GEOS. P. 407-408. [In Russian]

Tuniyev B.S. 1995. On the Mediterranean influence on the formation of herpetofauna of the Caucasian Isthmus and its main xerophylous refugia. Russian Journal of Herpetology 2(2): 95-119. DOI: 10.30906/1026-22961995-2-2-95-119

Tuniyev B.S. 2017. Modern state of the herpetofauna of Ritsa Relic National Park and new faunal finds in the Republic of Abkhazia. Proceedings of Ritsa Relic National Park 1: 120-130. [In Russian]

Tuniyev B.S., Tuniyev S.B. 2006a. Herpetofauna of Sochi National Park. In: B.S. Tuniyev (Ed.): Inventory of the main taxonomic groups and communities, sozological studies of Sochi National Park - the first results of Russia's first national park. Moscow: Prestizh. P. 195-204. [In Russian]

Tuniyev B.S., Tuniyev S.B. 2006b. Rare species of amphibians and reptiles of Sochi National Park. In: B.S. Tuniyev (Ed.): Inventory of the main taxonomic groups and communities, sozological studies of Sochi National Park - the first results of Russia's first national park. Moscow: Prestizh. P. 205-225. [In Russian]

Tuniyev B.S., Tuniyev S.B. 2007a. Banded newt - Triturus vittatus ophryticus (Berthold, 1846). In: A.S. Zamotajlov (Ed.): Red Data Book of the Krasnodar Territory (Animals). Krasnodar: Center of development of PTR of the Krasnodar Territory. P. 329-331. [In Russian]

Tuniyev B.S., Tuniyev S.B. 2007b. Colchis toad - Bufo verrucosissimus (Pallas, 1814). In: A.S. Zamotajlov (Ed.): Red Data Book of the Krasnodar Territory (Animals). Krasnodar: Center of development of PTR of the Krasnodar Territory. P. 332-333. [In Russian]

Tuniyev B.S., Bakradze M.A., Beregovaya S.Yu. 1987. On distribution and ecology of banded newt, Triturus vittatus (Jenyns, 1835). Proceedings of the Zoological Institute RAS 158: 161-169. [In Russian] 
Turbanov I.S., Oksinenko P.V., Kukushkin O.V. 2015. About records of reptiles (Reptilia) in the karst cavities of the Mountain Crimea. In: I.S. Turbanov, I.N. Marin, K.B. Gongalsky (Eds.): Biospelelogy of the Caucasus and other regions of Russia. Kostroma: Kostroma Publishing House. P. 90-94. [In Russian]

Turbanov I.S., Kukushkin O.V., Vargovitsh R.S. 2019. Amphibians and reptiles in the subterranean cavities of the Crimean Mountains. Russian Journal of Herpetology 26(1): 29-53. DOI: 10.30906/1026-22962019-26-1-29-53

Vargovitsh R., Monich O. 2004. Caves and adits of the Transcarpathians and their fauna. In: I. Zagorodniuk (Ed.): Cave fauna of Ukraine: proceedings of the Theriological School. Vol. 6. Kyiv. P. 191-216. [In Ukrainian]
Vekua A.K., Kalandadze K.S., Chkhikvadze V.M. 1979. New paleontological finds in Belaya Cave (Western Georgia). Bulletin of the Academy of Sciences of Georgian SSR 96(3): 745-748. [In Russian]

Zagorodniuk I., Petrushenko Ya. 2003. Amphibians as a component of cave faunistic groups in the territory of Ukraine. Visnyk of Lviv University. Biological Series 32: 165-171. [In Ukrainian]

Zagorodniuk I., Vargovitsh R. 2004. Checklist of cave fauna of Ukraine. In: I. Zagorodniuk (Ed.): Cave fauna of Ukraine: proceedings of the Theriological School. Vol. 6. Kyiv. P. 191-216. [In Ukrainian]

Zerova G.A., Chkhikvadze V.M. 1984. Overview of Cenozoic lizards and snakes of the USSR. Bulletin of the Academy of Sciences of Georgian SSR 10(5): 319-325. [In Russian]

\title{
ЗЕМНОВОДНЫЕ И ПРЕСМЫКАЮЩИЕСЯ В ПЕЩЕРАХ БОЛЬШОГО КАВКАЗА
}

\author{
Б. С. Туниев ${ }^{1}\left(\mathbb{D}\right.$, А. Г. Коваль ${ }^{(\mathbb{D})}$, Р. С. Варгович ${ }^{3}$ \\ ${ }^{1}$ Сочинский нацииональный парк, Россия \\ e-mail:btuniyev@mail.ru \\ ${ }^{2}$ Всероссийский научно-исследовательский институт зашиты растений, Россия \\ e-mail:agkoval@yandex.ru \\ ${ }^{3}$ Институт зоологии имени И.И. Шмальгаузена, Украина \\ e-mail:arete@izan.kiev.ua
}

Настоящее исследование является первым обзором рецентной герпетофауны пещер Большого Кавказа. Также следует отметить представленный небольшой объем материала (преимущественно плейстоценовый) по ископаемым амфибиям и рептилиям из пещер Большого Кавказа. Цель работы - восполнить пробелы в знаниях в этой области и представить многолетние данные о герпетофауне пещер Большого Кавказа. За период 1992-2019 гг. исследования проведены в 61 пещере Большого Кавказа в России, Абхазии и Грузии. Амфибии и рептилии были найдены в пещерах, расположенных в диапазоне высот от 55 м н.у.м. до 1300 м н.у.м. В общей сложности были отмечены 272 особи земноводных и пресмыкающихся, принадлежащие к десяти видам. Наиболее часто встречались: Rana macrocnemis (39.0\%), Pelodytes caucasicus (17.3\%), Bufo verrucosissimus (11.0\%), Darevskia brauneri (8.8\%), Hyla orientalis (8.1\%). Cуммарная доля остальных пяти видов (Ommatotriton ophryticus, Hyla savignyi, Pelophylax ridibundus, Anguis colchica и Darevskia derjugini) составила 15.8\%. Как правило, амфибии и рептилии в пещерах Большого Кавказа достаточно редки, и находки представлены единичными либо немногочисленными особями. Исключениями являются четыре пещеры. Это пещера Федоровская в Сочинском Причерноморье, а также пещеры Акшаша, Абшдза и Маршания Верхняя в Абхазии, в которых зафиксирована 141 особь амфибий и рептилий. Это составляет более половины (51.8\%) всех экземпляров, отмеченных в пещерах Большого Кавказа, относящихся к восьми видам (80\% от всех найденных видов). Пещеры предгорий, где наблюдается подавляющее большинство земноводных и рептилий, обычно характеризуются богатым фаунистическим разнообразием. Земноводные найдены как в привходовых, так и в глубоких и дальних частях пещер, тогда как ящерицы были обнаружены преимущественно вблизи входов, куда проникает свет и где в теплый период года сохраняется относительно высокая температура воздуха. Вероятно, определенная часть амфибий и рептилий Большого Кавказа проникает в пещеры целенаправленно (для зимовки и/или для питания). Другие представители герпетофауны, попадая в пещеры (особенно на дно вертикальных колодцев) случайно, становятся «узниками обстоятельств». Судя по продолжительности нахождения в пещерах и, как следствие, изменению окраски (осветление ее основного тона), а также хорошему внешнему состоянию многих особей, этих земноводных можно рассматриваться как субтроглофилов. Rana macrocnemis, иногда откладывающая в пещерах яйца, проявляет склонность к эвтроглофилии.

Ключевые слова: Абхазия, герпетофауна, Грузия, подземная полость, Россия, Сочинский национальный парк, субтроглофил, эвтроглофил 